Transactions of the American Fisheries Society, Vol. 127, No. 1, 1998, pp. 84-94.

(C) All rights reserved. American Fisheries Society.

http://afs.allenpress.com/perlserv/?request $=$ get-archive\&ct $=1$

http://afs.allenpress.com/archive/1548-8659/127/1/pdf/11548-8659-127-1-84.pdf

DOI: $10.1577 / 1548-8659(1998) 127<0084:$ PROAGS $>2.0 . C O ; 2$

ISSN: 0002-8487

\title{
Potential Regulation of Age-0 Gizzard Shad by Hybrid Striped Bass in Ohio Reservoirs
}

\author{
John M. Dettmers, Roy A. Stein, and Edward M. Lewis \\ Aquatic Ecology Laboratory, Department of Zoology, The Ohio State University.
}

Abstract. - Piscivores can control prey populations in north temperate lakes, leading to increased zooplankton and reduced phytoplankton. In reservoirs with gizzard shad Dorosoma cepedianum, an omnivorous planktivore, this cascade occurs with lower probability because while this fish is shorter than $60 \mathrm{~mm}$ in total length (TL) it readily consumes zooplankton but also switches to phytoplankton and detritus. Prospects for gizzard shad control probably hinge on piscivore consumption of age- 0 individuals. Hence, we quantified capture efficiency of hybrids of striped bass Morone saxatilis $\times$ white bass M. chrysops (small: 190-250 mm, TL; large: 310-360 mm, TL) when combined with three gizzard shad size-groups (of five possible, ranging 40-120 mm) in a 500-L aquarium. Small hybrid striped bass selected $40-\mathrm{mm}$ gizzard shad but preferred neither $60-\mathrm{mm}$ nor $80-\mathrm{mm}$ prey. Large hybrid striped bass demonstrated no selection for 40-120-mm gizzard shad. We incorporated these data into a bioenergetics model to evaluate whether hybrid striped bass could sufficiently reduce abundance of age- 0 gizzard shad in Ohio reservoirs to permit increased zooplankton, thereby improving the potential for resident sport fish recruitment in reservoirs. Hybrid striped bass potentially increased larval sport fish occurrence only when they were stocked at high densities ( $\geq 350 \mathrm{fish} / \mathrm{ha}$ or $\geq 22 \mathrm{~kg} / \mathrm{ha}$ ) coupled with age-0 gizzard shad suffering low natural mortality and occurring at an intermediate peak density of $25 \mathrm{fish} / \mathrm{m}^{3}$ or less. We believe gizzard shad are largely immune to control by hybrid striped bass in Ohio reservoirs. Hence, managers must consider combining watershed management with predator stocking to regulate gizzard shad.

The trophic cascade hypothesis provides an excellent framework for assessing food web interactions in aquatic systems (Carpenter et al. 1985; McQueen et al. 1989; Carpenter and Kitchell 1993). Typically, abundant piscivores consume planktivores, permitting increased zooplankton size and abundance and reducing phytoplankton abundance (Carpenter et al. 1987). This suite of trophic interactions occurs frequently and predictably in north-temperate oligomesotrophic lakes (Carpenter et al. 1987; McQueen et al. 1989; but see DeMelo et al. 1992). Managers can take advantage of these top-down effects not only to increase piscivore abundance (potentially improving the fishery; Kitchell 1992), but also to increase crustacean zooplankton (potentially improving recruitment of sport fishes; Stein et al. 1995, 1996; Dettmers et al. 1996) and to reduce phytoplankton (increasing water clarity; Carpenter et al. 1987).

In midlatitude reservoirs, gizzard shad Dorosoma cepedianum frequently dominates fish community biomass (Timmons et al. 1979; Miranda 1983; Willis and Jones 1986) because this species exhibits high fecundity (Vondracek and LeHew 1991), rapid growth, and limited vulnerability to piscivores (Adams and DeAngelis 1987; Johnson et al. 1988; Hambright et al. 1991; Stein et al. 1995). Simultaneously, gizzard shad impose control on lower trophic levels (Drenner et al. 1982a, 1982b; Dettmers and Stein 1992; DeVries and Stein 1992) without in turn being resource-limited by zooplankton or phytoplankton. Age-0 gizzard shad greater than $25 \mathrm{~mm}$ in total length (TL) can eliminate crustacean zooplankton populations (Dettmers and Stein 1992, 1996; DeVries and Stein 1992) before switching to phytoplankton and detritus (Miller 1960; Bodola 1966). Further, as age-0 gizzard shad grow from 30 to $60 \mathrm{~mm}$, the proportion of 
zooplankton they consume declines, remaining low for individuals longer than $60 \mathrm{~mm}$ (Yako et al. 1996). Because gizzard shad shorter than $60 \mathrm{~mm}$ probably regulate crustacean zooplankton abundance, this size-class probably compromises recruitment of sport fishes whose larvae depend on zooplankton during May-July (Stein et al. 1995). Conceivably, sport fish recruitment could be improved by regulating age- 0 gizzard shad with piscivores such that top-down effects result in increased crustacean zooplankton (Dettmers et al. 1996; Stein et al. 1996).

In Ohio reservoirs, only $20-30 \%$ of annual gizzard shad production is consumed by resident largemouth bass Micropterus salmoides (Carline et al. 1984) or stocked esocids and percids (Johnson et al. 1988), providing little opportunity for increased zooplankton through gizzard shad reduction. However, introduced piscivores, such as hybrids of striped bass Morone saxatilis $\times$ white bass $M$. chrysops, potentially can control shad populations in reservoirs, resulting in increased zooplankton (Stein et al. 1996). In 0.4-ha ponds, hybrid striped bass reduced age-0 gizzard shad abundance in a 5-week experiment, permitting crustacean zooplankton to persist at greater than $100 / \mathrm{L}$ when age-0 gizzard shad abundance was less than $10 / \mathrm{m}^{3}$ and daily zooplankton production exceeded $220 \mathrm{mg} / \mathrm{m}^{3}$ (Dettmers et al. 1996). As large, open-water piscivores, hybrid striped bass may provide the best opportunity for control of abundant gizzard shad, even though few field tests support the efficacy of introduced Morone piscivores as control agents of shad (Dettmers et al. 1996).

Control of prey populations depends, in part, on predator size selectivity. If piscivores prefer gizzard shad less than $60 \mathrm{~mm}$, zooplankton are more likely to increase. From 32 laboratory and field studies that quantified piscivore prey preference, piscivores almost universally (91 of 93 cases) selected prey sizes equal to or smaller than the average size available (Juanes 1994). More specifically, hybrid striped bass selected smaller gizzard shad than the mean size available in ponds (Dettmers et al. 1996) and rarely ate gizzard shad longer than $65 \mathrm{~mm}$ in West Point Reservoir, Alabama and Georgia (Ott and Malvestuto 1984).

By incorporating these piscivore diet patterns into bioenergetics models, prey population responses can be predicted, given piscivore growth rates. For example, bioenergetics modeling applied to Lake Michigan predicted that salmonine consumption, owing to high stocking rates in the early 1980s, could collapse populations of alewife Alosa pseudoharengus (Stewart et al. 1981).

To assess the potential for piscivore-mediated increases in zooplankton abundance, information on piscivore size selectivity and consumptive demand is required. In particular, we hypothesized that hybrid striped bass may consume sufficient age-0 gizzard shad to increase zooplankton, potentially improving recruitment of sport fishes with zooplanktivorous larvae. Thus, we quantified size selectivity of hybrid striped bass for age- 0 gizzard shad and then used a bioenergetics model to estimate consumptive demand of hybrid striped bass to determine if these piscivores could reduce age- 0 gizzard shad and thereby increase zooplankton.

\section{Methods}

Laboratory experiments. - To quantify size selectivity, we conducted 30-min experiments in a $2.0 \times 0.5 \times 0.5 \mathrm{~m}, 500$-L tank at $17-21^{\circ} \mathrm{C}$ with a photoperiod of $12 \mathrm{~h} \mathrm{light:12 \textrm {h }}$ dark. The tank was divided into a predator chamber $(440 \mathrm{~L})$ and a prey chamber $(60 \mathrm{~L})$ by an opaque divider. With a window $(1.35 \times 0.30 \mathrm{~m})$ in the tank and a mirror $(1.42 \times 0.41 \mathrm{~m})$ above the tank, a predator could be observed throughout the tank. 
TABLE 1.- Summary of the experimental design used for the laboratory size-selection experiments; TL = total length; $N=$ number of fish used in a treatment. Each piscivore completed three to five trials within a treatment. No small hybrid striped bass successfully fed on the large size-group of gizzard shad. We used five gizzard shad in each size-class and three size-classes in each size-group.

\begin{tabular}{ccllc}
\hline \multicolumn{2}{l}{ Hybrid striped bass } & & \multicolumn{2}{c}{ Gizzard shad } \\
\cline { 1 - 2 } \cline { 4 - 5 } TL $(\mathrm{mm})$ & $N$ & & Size-group & Size class $(\mathrm{TL}, \mathrm{mm})$ \\
\hline $190-250$ & 5 & & Small & $40,60,80$ \\
& 3 & & Intermediate & $60,80,100$ \\
$310-360$ & 1 & & Small & $40,60,80$ \\
& 3 & & Intermediate & $60,80,100$ \\
& 1 & & Large & $80,100,120$ \\
\hline
\end{tabular}

Hybrid striped bass were obtained from the Hebron State Fish Hatchery and from Buckeye Lake in Licking, Fairfield, and Perry counties, Ohio. We measured total length, mouth depth, and mouth width to quantify the maximum size of prey these fish could consume. Between experiments, hybrid striped bass were fed gizzard shad and fathead minnow Pimephales promelas. For gizzard shad collected from nearby reservoirs, total length and body depth were measured to determine the morphometric relationship between them. Gizzard shad were fed nauplii of Artemia sp. and commercial fish food, whereas fathead minnow were fed only commercial fish food.

To quantify size selection by hybrid striped bass, we combined a single predator with 15 gizzard shad-five fish from each of three size-classes (which together composed a sizegroup) - in each trial. A size-group of gizzard shad was combined with either small (190-250 $\mathrm{mm})$ or large $(310-360 \mathrm{~mm})$ hybrid striped bass. All three size-groups of prey $(40-80 \mathrm{~mm}, 60-$ $100 \mathrm{~mm}$, or $80-210 \mathrm{~mm}$ ) were combined with small and large piscivores, except that no small piscivores were exposed to the largest size-group of gizzard shad (Table 1). We included gizzard shad within a size-class if they were within $5 \mathrm{~mm}$ of the nominal size (e.g., $40-\mathrm{mm}$ size-class: 35-45 mm). Individual piscivores were starved for $24 \mathrm{~h}$ before each trial.

Gizzard shad were added to the prey chamber $15 \mathrm{~min}$ before each experiment. Prey were combined with the piscivore by removing the divider, creating a single experimental chamber. We quantified attacks on all prey and captures by the piscivore; capture efficiency was calculated as the number of captures divided by number of attacks. Experiments ended after 30 min or upon consumption of one gizzard shad, whichever came first. Remaining gizzard shad were then removed and measured.

One to five individuals per piscivore size-class were tested, with three to five trials per predator to quantify the variability in consumption patterns of individual hybrid striped bass. All statistical comparisons between gizzard shad size-groups used the mean responses of each piscivore across all trials. Whether hybrid striped bass preferred particular prey sizes was tested with a chi-square contingency test. We used one-way analysis of variance (ANOVA) with Tukey's multiple comparisons to evaluate capture efficiency; these data were arc-sine transformed to approximate a normal distribution. Linear regression described relationships between total length and mouth gape or body depth.

Bioenergetics model. - We used a bioenergetics model (Hewett and Johnson 1992) to estimate hybrid striped bass growth and food consumption. The model runs on a daily time step and uses the following balanced-energy relationship: 


$$
G=C-(R+S+F+U)
$$

where growth $(G)$ is expressed as energy consumed $(C)$ minus the costs of metabolism $(R)$, specific dynamic action $(S)$, egestion $(F)$, and excretion $(U)$. We used the model parameters developed for striped bass (Hartman and Brandt 1993), except that we increased $\theta_{2}$ and $\theta_{3}$ to $25^{\circ} \mathrm{C}$ and $\theta_{4}$ to $30^{\circ} \mathrm{C}$ to account for the increased optimal feeding temperature of hybrid striped bass (Woiwode and Adelman 1991).

With this model, we evaluated the potential for hybrid striped bass to reduce age- 0 gizzard shad to fewer than $10 / \mathrm{m}^{3}$ (the critical threshold at which productive zooplankton populations can persist with age-0 gizzard shad; Dettmers and Stein 1996) before August 1. In Ohio reservoirs, zooplanktivorous sport fish larvae occur through early August (DeVries et al. 1991); hence, if piscivores reduce age-0 gizzard shad and increase zooplankton via the trophic cascade by August 1, zooplanktivorous sport fishes may recruit successfully. We permitted hybrid striped bass to consume only those gizzard shad within their morphological limits of consumption based on our laboratory results. These physical constraints applied to age- 0 and age-1 hybrid striped bass, which were forced to consume alternative fish prey or invertebrates after age-0 gizzard shad had grown beyond the predators' maximum gape.

We simulated the impact of a hybrid striped bass population consisting of three cohorts (ages 0-2) on an age-0 gizzard shad cohort spawned on May 15 in a generalized 65-ha Ohio reservoir with a mean depth of $2 \mathrm{~m}$. Annual temperatures ranged from $4^{\circ} \mathrm{C}$ during DecemberMarch to $30^{\circ} \mathrm{C}$ for about 10 days in July; temperatures above $15^{\circ} \mathrm{C}$ occurred during JuneOctober. Consumption by hybrid striped bass was estimated across three annual stocking rates: $125 \mathrm{fish} / \mathrm{ha}$, the usual stocking rate of hybrid striped bass in Ohio waters (J. Marshall, Ohio Division of Wildlife, personal communication), and 350 and 500 fish/ha. These stocking rates yielded standing stocks of 8, 22 (the hybrid striped bass density used in 0.4-ha ponds to maintain zooplankton density above 100/L; Dettmers et al. 1996), and $32 \mathrm{~kg} / \mathrm{ha}$, respectively, after 3 years of sustained stocking. We assumed that age- 0 hybrid striped bass were stocked when $50 \mathrm{~mm}$ long. We further assumed annual hybrid striped bass mortality was $90 \%$ during the first year of life, a rate similar to that observed for other stocked piscivores (Wahl and Stein 1993; Stahl et al. 1996), and 50\% thereafter with zero fishing mortality.

Hybrid striped bass diets and growth were derived from Austin and Hurley (1987). Age-0 hybrid striped bass weighed $13 \mathrm{~g}$, age-1 fish weighed $503 \mathrm{~g}$, and age- 2 fish weighed 1,778 $\mathrm{g}$ at the end of each growing season. The proportion of maximum consumption ( $P$-value) required by each age-class of hybrid striped bass to reach its observed growth given our diet information was 1.11 for age- $0,0.82$ for age-1, and 0.61 for age-2. When hybrid striped bass consumed fish, we assumed that only gizzard shad were eaten unless gizzard shad exceeded the morphological limits of consumption, thus maximizing the potential impact of hybrid striped bass on gizzard shad. We further assumed that hybrid striped bass ate age-0 gizzard shad only after they grew larger than $20 \mathrm{~mm}$ and that age-0 gizzard shad did not persist in the reservoir after January 1 because of winterkill (J. M. Dettmers, personal observation). Thus, we only explored hybrid striped bass predation on a single year-class of gizzard shad during June 1-December 31 . 


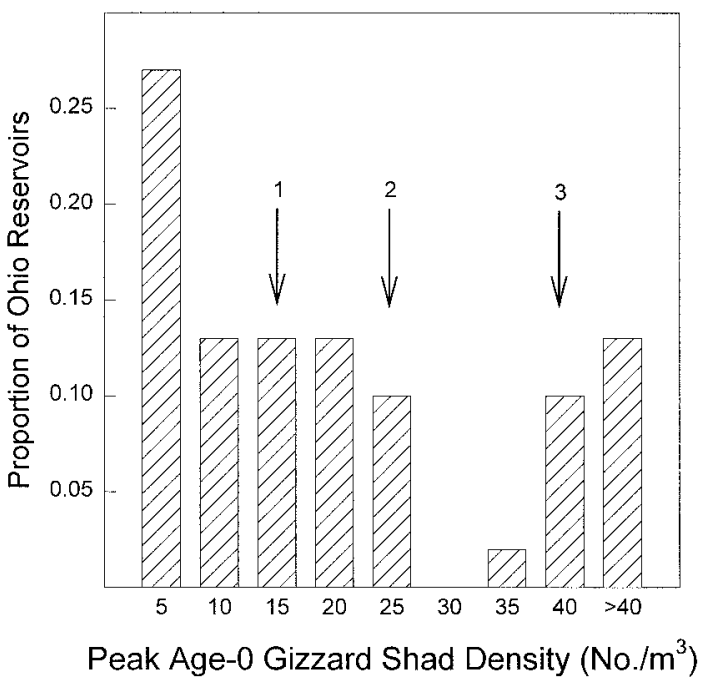

FIGURE 1.-Distribution of peak densities of larval gizzard shad across Ohio reservoirs. This data set comprises 48 reservoir-years from 18 reservoirs sampled through as many as 5 years (Bremigan et al. 1991; DeVries et al. 1991; Dettmers and Stein 1992, 1996; DeVries and Stein 1992; Donovan et al. 1997; Aquatic Ecology Laboratory, Ohio State University, unpublished data). Arrows depict the densities used in our bioenergetics modeling scenarios.

To further bracket the potential piscivore impact, we evaluated hybrid striped bass consumption against two annual mortality schedules for age-0 gizzard shad: 99 and 99.99\%, which have been observed for age-0 fishes in marine and freshwater habitats (Dey 1981; Timmons et al. 1981; Crecco et al. 1983). These mortality schedules reflected mean survivorship from hatching until the end of the first year of life. They do not include potential differences in mortality as gizzard shad grow and pass through critical developmental bottlenecks (sensu Hjort 1914) because that specific information on stage-dependent mortality currently is not available for gizzard shad. Initial age-0 gizzard shad densities were 15,25 , and $40 / \mathrm{m}^{3}$ to span a range of common densities found in Ohio reservoirs where gizzard shad exceed $10 / \mathrm{m}^{3}$ (Figure 1). Our simulations began with $20-\mathrm{mm}(0.02-\mathrm{g})$ gizzard shad that grew an average of $0.4 \mathrm{~mm} / \mathrm{d}$ during June 1-November 1 until reaching $80 \mathrm{~mm}(5.69 \mathrm{~g})$, after which growth stopped.

\section{Results}

Size Selection - When exposed to the small size-group of gizzard shad (Table 1), small hybrid striped bass preferred 40-mm prey (chi-square contingency test, df $=2 ; P=0.0002$; Figure 2A). These smallest gizzard shad represented $78 \%$ of all prey eaten, whereas $80-\mathrm{mm}$ gizzard shad never were consumed. A single large hybrid striped bass preferred no size class in the small gizzard shad group (chi-square contingency test, $\mathrm{df}=2 ; P=0.78$; Figure $2 \mathrm{~B}$ ).

With the intermediate gizzard shad size-group, small hybrid striped bass marginally preferred 60-mm prey (chi-square contingency test, $\mathrm{df}=2 ; P=0.06$; Figure 2A). Large hybrid striped bass preferred no particular size-class within this size-group (chi-square contingency test, $\mathrm{df}=2 ; P=0.72$; Figure $2 \mathrm{~B}$ ). A single large hybrid striped bass also preferred no specific sizeclass when exposed to the large gizzard shad size-group (chi-square contingency test, $\mathrm{df}=2 ; P=$ 0.67 ; Figure 2B). 


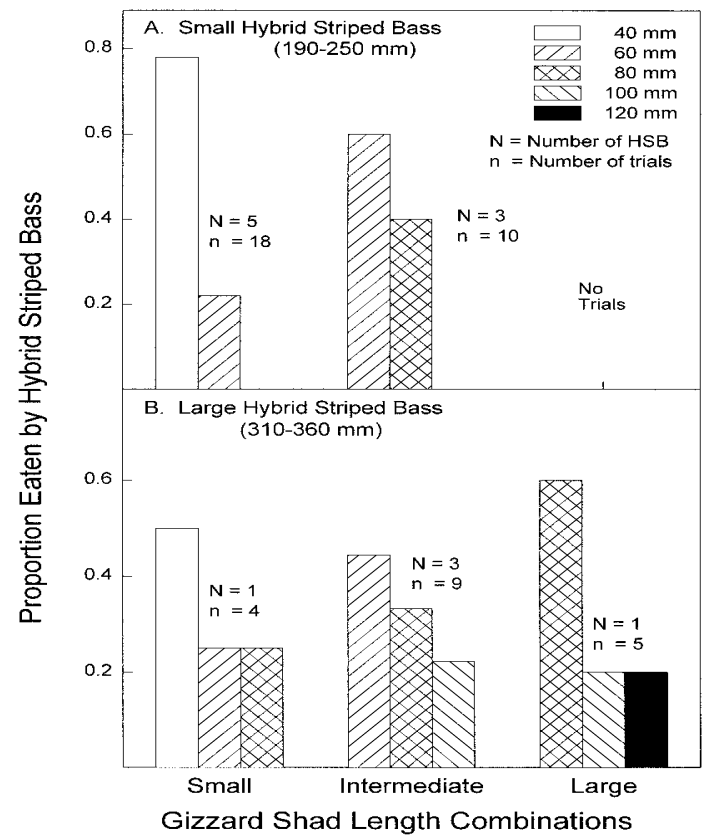

FIGURE 2.-Proportions of gizzard shad size-classes within size-groups eaten by all (A) small and (B) large hybrid striped bass (HSB) when feeding in a 500-L aquarium; $N$ is the number of individual hybrid striped bass used for each size-group; $n$ is the total number of trials completed by the $N$ hybrid striped bass. Small, intermediate, and large refer to gizzard shad size-groups (see Table 1).

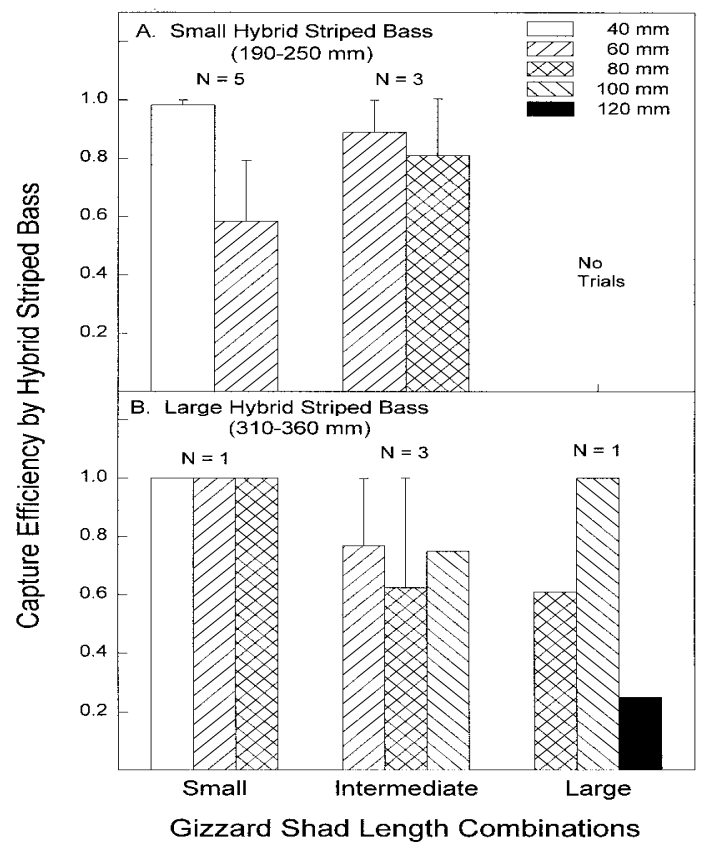

FIGURE 3.-Mean (+SE) capture efficiency (number of captures per attack) by (A) small and (B) large hybrid striped bass when feeding on each gizzard shad size-group in a 500-L aquarium. $N$ is the number of hybrid striped bass used with each of the small, intermediate, and large gizzard shad size-groups (see Table 1). 
Capture efficiency by small hybrid striped bass for the small gizzard shad size-group was marginally higher for $40-\mathrm{mm}$ prey compared with $60-\mathrm{mm}$ prey (ANOVA, $F=5.24$; $\mathrm{df}=1,6 ; P$ $=0.06$; Figure $3 \mathrm{~A}$ ). Conversely, attacks on small prey always ended with a capture for large hybrid striped bass, regardless of prey size-class within the group (Figure 3B).

Small hybrid striped bass captured $60-\mathrm{mm}$ and $80-\mathrm{mm}$ gizzard shad with similar efficiency when feeding on the intermediate size-group of prey (ANOVA, $F=0.04 ; \mathrm{df}=1,4 ; P$ $=0.84$; Figure $3 \mathrm{~A}$ ). Capture efficiency by large hybrid striped bass also did not differ across prey sizes-classes within this size-group (ANOVA, $F=0.08$; df $=2,3 ; P=0.92$; Figure $3 \mathrm{~B}$ ). However, a single large hybrid striped bass was most efficient at capturing 100 -mm prey and least efficient at capturing 120-mm prey when exposed to the large size-group of gizzard shad (Figure 3B).

Because capture efficiency of hybrid striped bass did not decline as prey size increased (ANOVA, $F=0.37, \mathrm{df}=2,2 ; P=0.73$; efficiency range $0.75-1.00$ for large hybrid striped bass; $F=0.71$, df $=1,6 ; P=0.43$; efficiency range $0.83-0.92$ for small hybrid striped bass), we estimated the largest prey that predators could consume by comparing gizzard shad body depth to hybrid striped bass mouth width. Hybrid striped bass efficiently consumed prey that were at their morphological limits of consumption. For hybrid striped bass shorter than $250 \mathrm{~mm}$, the largest potential prey size was $80 \mathrm{~mm}$ (body depth $=22 \mathrm{~mm}$ ), whereas for hybrid striped bass of $310-360 \mathrm{~mm}$, the largest potential prey size was $120 \mathrm{~mm}$ (body depth $=32 \mathrm{~mm}$ ). Regressing capture efficiency against the proportion of the maximum gape for each prey, we found no relationship for either predator size (linear regression, $F=0.07$, $\mathrm{df}=1,8 ; P=0.80$ for large hybrid striped bass; $F=0.30, \mathrm{df}=1,12 ; P=0.60$ for small hybrid striped bass). Consequently, hybrid striped bass in the laboratory can consume prey whose limiting dimension equals their maximum gape without reducing capture efficiency.

Bioenergetics Modeling - We determined if consumption by hybrid striped bass could reduce age- 0 gizzard shad density to $10 / \mathrm{m}^{3}$ before August 1 . We chose this date as the last one that limnetic larval sport fishes could reasonably benefit from increased zooplankton.

When peak age-0 gizzard shad density was $40 / \mathrm{m}^{3}$ (mean gizzard shad TL, $20 \mathrm{~mm}$ ), gizzard shad abundance did not decline to less than $10 / \mathrm{m}^{3}$ in the absence of hybrid striped bass predation until October 1 if natural mortality was low (99\%; Figure 4C) or until July 1 if mortality was high (99.99\%; Figure 5C). Hybrid striped bass consumption could not effect appropriate control when gizzard shad mortality was low but did increase the potential window for increased zooplankton by about 2 weeks when hybrid striped bass biomass exceeded 22 $\mathrm{kg} / \mathrm{ha}$ and gizzard shad mortality was high.

Without hybrid striped bass, age-0 gizzard shad density declined from a peak of $25 / \mathrm{m}^{3}$ to less than $10 / \mathrm{m}^{3}$ on August 20 when natural mortality was low (Figure 4B), and on June 15 when mortality was high (Figure 5B). At high gizzard shad mortality, hybrid striped bass at $22 \mathrm{~kg} / \mathrm{ha}$ or greater eliminated age- 0 gizzard shad by December 1 but did not appreciably change the date on which gizzard shad density fell below $10 / \mathrm{m}^{3}$ (Figure 5B). When present at $32 \mathrm{~kg} / \mathrm{ha}$, hybrid striped bass reduced age- 0 gizzard shad to $10 / \mathrm{m}^{3}$ by August 1 even when gizzard shad mortality was low (Figure 4B). 


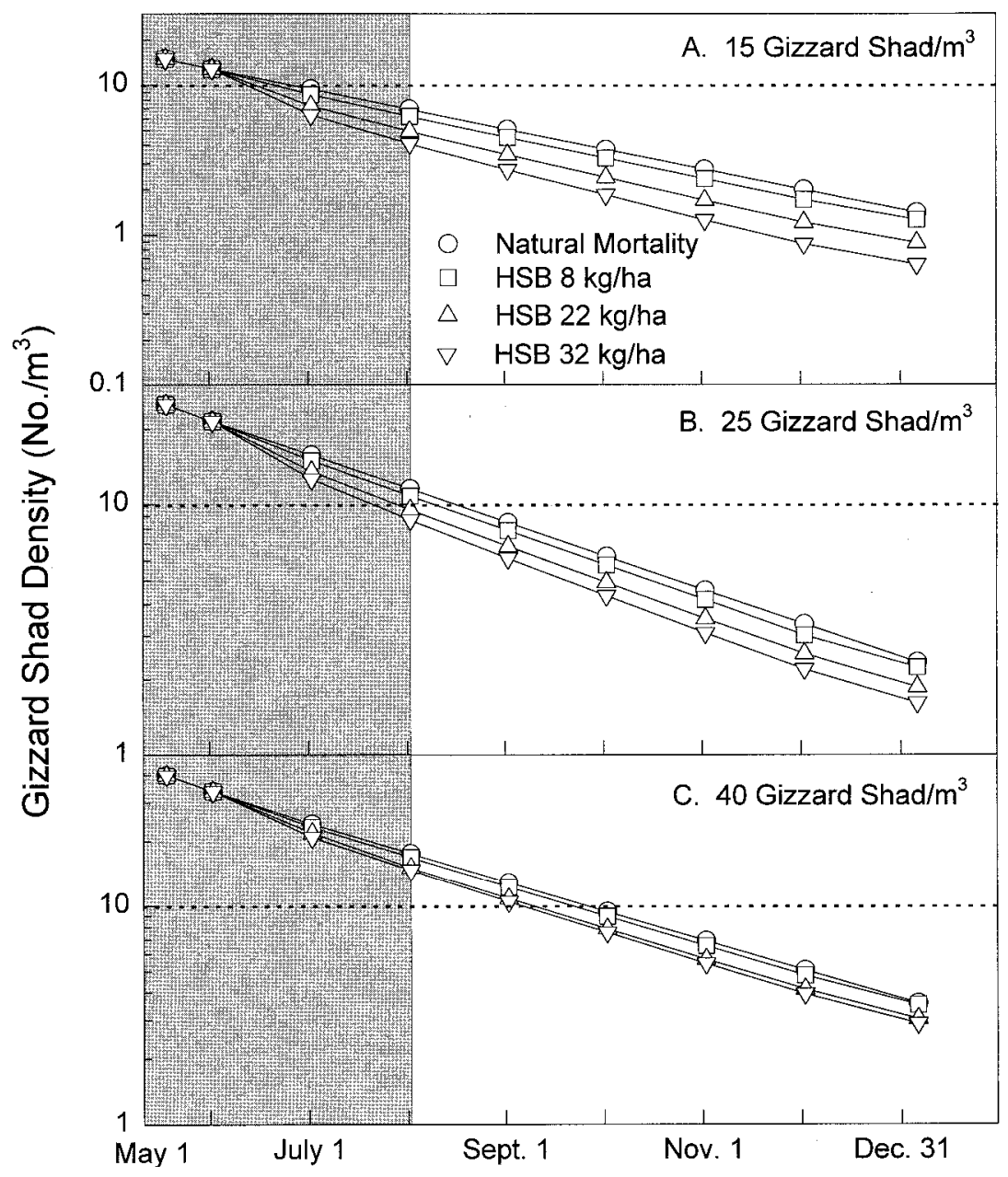

FIGURE 4.-Results of bioenergetics model for lakewide age-0 gizzard shad abundance during May 15-December 31 , assuming a natural gizzard shad mortality of $99 \%$ and peak gizzard shad abundance of (A) $15 / \mathrm{m}^{3}$, (B) $25 / \mathrm{m}^{3}$, or (C) $40 / \mathrm{m}^{3}$. Changes in age- 0 gizzard shad abundance resulting from consumption by hybrid striped bass (HSB) stocked to achieve densities of 8,22 , and $32 \mathrm{~kg} / \mathrm{ha}$ also are plotted. The shaded portion of the figure corresponds to larval sport fish presence in the limnetic zone.

When peak age-0 gizzard shad density was $15 / \mathrm{m}^{3}$ and natural mortality was high, their abundance decreased to less than $10 / \mathrm{m}^{3}$ before hybrid striped bass began consuming gizzard shad (Figure 5A). At low natural mortality, gizzard shad abundance was less than $10 / \mathrm{m}^{3}$ by July 1 (Figure 4A). Coupled with this low mortality rate, hybrid striped bass present at $32 \mathrm{~kg} / \mathrm{ha}$ reduced age- 0 gizzard shad to less than $10 / \mathrm{m}^{3}$ on June 12 (Figure 4A). At high natural mortality, hybrid striped bass eliminated age-0 gizzard shad before December 1 regardless of predator stocking density (Figure 5A).

When natural gizzard shad mortality was low, hybrid striped bass never eliminated age-0 gizzard shad by December 31 (Figure 4). Hybrid striped bass contributed only marginally to overall gizzard shad mortality at low natural mortality because even high piscivore stocking rates failed to reduce gizzard shad density to less than $10 / \mathrm{m}^{3}$ before August 1 from initial densities of $25 / \mathrm{m}^{3}$ or greater (Figure 4). At high natural mortality, hybrid striped bass present at $22 \mathrm{~kg} / \mathrm{ha}$ or greater eliminated gizzard shad, regardless of their initial abundance; hybrid striped bass present 
at $8 \mathrm{~kg} /$ ha eliminated gizzard shad only when they were initially abundant at $15 / \mathrm{m}^{3}$ (Figure 5).

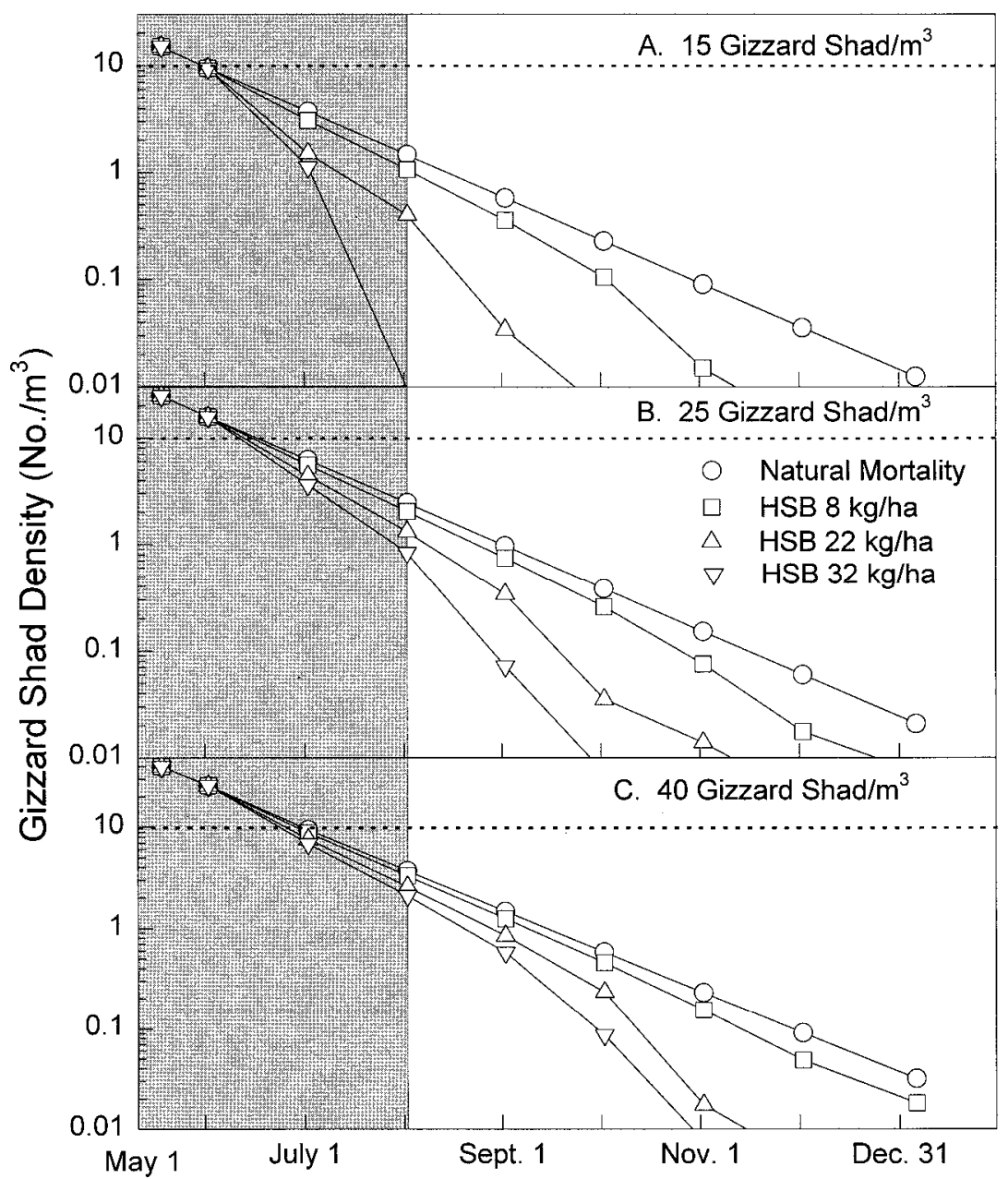

FIGURE 5.- Results of bioenergetics model for lakewide age-0 gizzard shad abundance during May 15-December 31 , assuming a natural gizzard shad mortality of $99.99 \%$ and peak gizzard shad abundance of (A) $15 / \mathrm{m}^{3}$, (B) $25 / \mathrm{m}^{3}$, or (C) $40 / \mathrm{m}^{3}$. Changes in age-0 gizzard shad abundance resulting from consumption by hybrid striped bass (HSB) stocked to achieve densities of 8,22 , and $32 \mathrm{~kg} / \mathrm{ha}$ also are plotted. The shaded portion of the figure corresponds to larval sport fish presence in the limnetic zone.

\section{Discussion}

We quantified size selectivity by hybrid striped bass for gizzard shad, incorporated these data into a bioenergetics model, and determined that hybrid striped bass are unlikely to regulate gizzard shad populations in small Ohio reservoirs under most scenarios. Only with hybrid striped bass biomass at $22 \mathrm{~kg} / \mathrm{ha}$ or greater and initial age- 0 gizzard shad density at $25 / \mathrm{m}^{3}$ or less can these piscivores sufficiently reduce gizzard shad to potentially improve sport fish recruitment while simultaneously maintaining their preferred prey base. Similarly, $22 \mathrm{~kg} / \mathrm{ha}$ of hybrid striped bass reduced a peak density of $25 / \mathrm{m}^{3}$ age- 0 gizzard shad within 3 weeks in short-term pond experiments, permitting increased zooplankton (Dettmers et al. 1996). 
Hybrid striped bass at less than $250 \mathrm{~mm}$ preferred 40-mm gizzard shad when exposed to the small-sized prey group, a preference that weakened when these small predators were combined with the intermediate size-group of gizzard shad. Hybrid striped bass greater than 310 $\mathrm{mm}$ did not exhibit size selectivity, although only one fish was tested in two of the three sizegroups. Hybrid striped bass consistently consumed more small gizzard shad in each size-group. However, both large and small hybrid striped bass consumed prey as wide as their mouth gape without compromising capture efficiency.

In the field, piscivores consume smaller prey than predicted by optimality considerations (Juanes 1994). Hybrid striped bass from West Point Reservoir rarely consumed gizzard shad longer than $65 \mathrm{~mm}$ despite being capable of doing so (Ott and Malvestuto 1984). In short-term pond experiments, hybrid striped bass ate smaller gizzard shad than the mean size that was available (Dettmers et al. 1996).

In our view, preference for small prey cannot be explained by reduced capture efficiency as prey size approaches piscivore gape constraints. Rather, this preference appears to derive from interactions between piscivore and prey that operate at larger spatial scales than our observation chamber. Vulnerability can be reduced through habitat choice, schooling, and escape responses (Savino and Stein 1982; Pitcher 1986; Christensen and Persson 1993). Spatial overlap among piscivores and prey, mediated by temperature and dissolved oxygen preferences (Coutant 1985), as well as reduced piscivore search efficiency within highly turbid conditions also can reduce prey susceptibility (Miner 1990; Miner and Stein 1996) and may result in piscivores consuming only small, vulnerable prey. Finally, because age- 0 gizzard shad are the most abundant fish in Ohio reservoirs during summer and fall (Johnson 1986), hybrid striped bass are simply more likely to encounter these small prey. This combination of factors may cause hybrid striped bass and many other piscivores to consume smaller prey in the field than may be predicted by morphological limits.

Because gizzard shad shorter than $60 \mathrm{~mm}$ probably regulate spring and summer zooplankton populations (Dettmers and Stein 1992; DeVries and Stein 1992; Yako et al. 1996), the success of hybrid striped bass in regulating gizzard shad depends not only on gizzard shad consumption but also on system productivity and the timing of sport fish spawning relative to that of gizzard shad. Bioenergetics simulations revealed that abundant hybrid striped bass may hasten the decline in age- 0 gizzard shad to less than $10 / \mathrm{m}^{3}$ by as much as 4 weeks. However, if gizzard shad abundance initially exceeds $25 / \mathrm{m}^{3}$, reductions to 10 gizzard shad $/ \mathrm{m}^{3}$ are not realized until August or later, too late in the season for increased zooplankton to improve sport-fish recruitment, regardless of productivity. Further, when initial gizzard shad abundance was 15$25 / \mathrm{m}^{3}$, only stocking hybrid striped bass at densities three to four times greater than management agencies typically stock these piscivores (Crandall 1979; Morris and Follis 1979; Ott and Malvestuto 1984; Jahn et al. 1987) caused gizzard shad declines by mid-July, a conclusion consistent with the experimental results of Dettmers et al. (1996). Age-0 gizzard shad densities of $15-25 / \mathrm{m}^{3}$ occur in as much as $35 \%$ of Ohio reservoirs and could be manipulated with aggressive piscivore stocking to increase sport fish recruitment. However, to improve sport fish recruitment, zooplankton enhancement must occur when sport fishes are zooplanktivorous in the limnetic zone. Any combination of piscivores must reduce age- 0 gizzard shad density to less than $10 / \mathrm{m}^{3}$ by August 1 to permit zooplankton to persist at 100/L for late-hatching sport fishes (DeVries et al. 1991). In turn, zooplankton are likely to persist at densities greater than 100/L only if daily zooplankton production exceeds $220 \mathrm{mg} / \mathrm{m}^{3}$ (Dettmers et al. 1996). Thus, hybrid striped bass have the potential to improve sport fish recruitment only in the most productive 
reservoirs with less than 25 age- 0 gizzard shad $/ \mathrm{m}^{3}$, a condition we expect in less than $5 \%$ of Ohio reservoirs (Dettmers et al. 1996). Further, the dense stocking rates needed to maintain predation pressure by hybrid striped bass on gizzard shad may, in turn, reduce piscivore growth rates, causing this strategy by itself to be less attractive to managers.

When natural mortality of age-0 gizzard shad was high, their density decreased to less than $10 / \mathrm{m}^{3}$ before mid-July, regardless of hybrid striped bass predation. As a result, hybrid striped bass consumed all age-0 gizzard shad in at least two predation scenarios for each gizzard shad density, but their consumption by hybrid striped bass would not have permitted an earlier zooplankton resurgence. Under these scenarios, hybrid striped bass must consume other fishes during winter and spring, also a potentially undesirable management outcome. If gizzard shad mortality is high, survival of hybrid striped bass may be compromised given their strong preference for shad (Crandall 1979; Layzer and Clady 1984).

Given that hybrid striped bass stocking alone will not release zooplankton from regulation by gizzard shad, multiple and simultaneous management actions probably are appropriate. Further, gizzard shad consumption by largemouth bass in Ohio reservoirs averages only about $25 \%$ of our maximum estimate (Carline et al. 1984), suggesting that consumption by resident piscivores most often is substantially less than that by hybrid striped bass.

Because both phosphorus and turbidity correlate well with larval gizzard shad production (Bremigan 1997), management actions in the watershed, such as increasing the riparian zone, could reduce nutrient input as well as sediment loading. In this fashion, the recruitment environment for gizzard shad would become less favorable. Coupling hybrid striped bass stocking with watershed management perhaps could reduce gizzard shad sufficiently to effect enhanced zooplankton, creating a more favorable environment for sport fish recruitment (Stein et al. 1996).

Our modeling revealed that, although hybrid striped bass can reduce age- 0 gizzard shad, only rarely did reduction occur during mid-June through July when increased zooplankton could improve the recruitment environment for sport fishes. Even with liberal piscivore stocking, predation-induced gizzard shad reduction frequently occurred after August 1, too late to benefit sport fish recruitment. Thus, in more than $95 \%$ of shallow, turbid, eutrophic reservoirs similar to systems in Ohio, we do not expect hybrid striped bass or any other piscivore to improve sport fish recruitment by consuming gizzard shad. Rather, ecosystem management that includes piscivore stocking as part of a larger watershed improvement plan may be more appropriate.

\section{Acknowledgments}

We thank K. Jenks, B. Kennedy, M. Raffenberg, S. Strong-Betz, G. Thiede, and L. Yako for their help in the laboratory and field. Hybrid striped bass for the experiments were graciously provided by J. Stafford and D. Walters of the Ohio Division of Wildlife (ODW). An anonymous reviewer and J. Ney, L. Rudstam, and L. Einfalt provided comments on an earlier draft, substantially improving the manuscript. This work was funded by Federal Aid in Sport Fish Restoration projects F-57-R and F-69-P, which were administered jointly by the U.S. Fish and Wildlife Service and the ODW, and by National Science Foundation grants DEB-9107173 and DEB-9407859 to R.A.S.

\section{References}

Adams, S. M., and D. L. DeAngelis. 1987. Indirect effects of early bass-shad interactions on predator population structure and food web dynamics. Pages 103-117 in W. C. Kerfoot and A. Sih, editors. Predation: direct and indirect impacts on aquatic communities. University Press of New England, Hanover, New Hampshire. 
Austin, M. R., and S. T. Hurley. 1987. Evaluation of a striped bass female (Morone saxatilis) $\times$ white bass male $(M$. chrysops) hybrid introduction in East Fork Lake, Ohio. Ohio Department of Natural Resources, Federal Aid in Sport Fish Restoration, Project F-29-R, Final Report, Columbus.

Bodola, A. 1966. Life history of the gizzard shad, Dorosoma cepedianum (LeSueur), in western Lake Erie. Fishery Bulletin 65:391-425.

Bremigan, M. T. 1997. Variable recruitment of gizzard shad, a strong interactor in reservoirs: exploring causal mechanisms and implications for food webs. Doctoral dissertation. Ohio State University, Columbus.

Bremigan, M. T., E. M. Lewis, M. B. Jones, R. A. Stein, and D. R. DeVries. 1991. Evaluating effects of stocking threadfin shad on young-of-year crappie, bluegill, and largemouth bass in Ohio lakes. Ohio Department of Natural Resources, Federal Aid in Sport Fish Restoration, Project F-57-R, Final Report, Columbus.

Carline, R. F, B. L. Johnson, and T. J. Hall. 1984. Estimation and interpretation of proportional stock density for fish populations in Ohio impoundments. North American Journal of Fisheries Management 4:139-154.

Carpenter, S. R., and J. F. Kitchell. 1993. The trophic cascade in lakes. Cambridge University Press, New York.

Carpenter, S. R., J. F Kitchell, and J. R. Hodgson. 1985. Cascading trophic interactions and lake productivity. BioScience 35:634-639.

Carpenter, S. R., and nine coauthors. 1987. Regulation of lake primary productivity by food web structure. Ecology 68:1863-1876.

Christensen, B., and L. Persson. 1993. Species-specific antipredatory behaviours: effects on prey choice in different habitats. Behavioral Ecology and Sociobiology 32:1-9.

Coutant, C. C. 1985. Striped bass, temperature, and dissolved oxygen: a speculative hypothesis for environmental risk. Transactions of the American Fisheries Society 114:31-61.

Crandall, P. S. 1979. Evaluation of striped bass $\times$ white bass hybrids in a heated Texas reservoir. Proceedings of the Annual Conference Southeastern Association of Fish and Wildlife Agencies 32(1978):588-598.

Crecco, V., T. Savoy, and L. Gunn. 1983. Daily mortality rates of larval and juvenile American shad (Alosa sapidissima) in the Connecticut River with changes in year-class strength. Canadian Journal of Fisheries and Aquatic Sciences 40:1719-1728.

DeMelo, R., R. France, and D. J. McQueen. 1992. Biomanipulation: hit or myth? Limnology and Oceanography 37:192-207.

Dettmers, J. M., D. R. DeVries, and R. A. Stein. 1996. Reservoir biomanipulation: quantifying piscivore effects and prey productivity across multiple trophic levels. Transactions of the American Fisheries Society 125:491504.

Dettmers, J. M., and R. A. Stein. 1992. Food consumption by larval gizzard shad: zooplankton effects and its implications for reservoir communities. Transactions of the American Fisheries Society 121:494-507.

Dettmers, J. M., and R. A. Stein. 1996. Quantifying linkages among gizzard shad, zooplankton, and phytoplankton in reservoirs. Transactions of the American Fisheries Society 125:27-41.

DeVries, D. R., and R. A. Stein. 1992. Complex interactions between fish and zooplankton: quantifying the role of an open-water planktivore. Canadian Journal of Fisheries and Aquatic Sciences 49:1216- 1227.

DeVries, D. R., R. A. Stein, J. G. Miner, and G. G. Mittelbach. 1991. Stocking threadfin shad: consequences for young-of-year fishes. Transactions of the American Fisheries Society 120:368-381.

Dey, W. P. 1981. Mortality and growth of young-of-the-year striped bass in the Hudson River estuary. Transactions of the American Fisheries Society 110:151-157.

Donovan, N. S., R. A. Stein, and M. M. White. 1997. Enhancing percid stocking success through an understanding of age-0 piscivore-prey interactions in reservoirs. Ecological Applications 7:1311-1329.

Drenner, R. W., F. DeNoyelles, and D. Kettle. 1982a. Selective impact of filter-feeding gizzard shad on zooplankton community structure. Limnology and Oceanography 27:965-968.

Drenner, R. W., W. J. O'Brien, and J. R. Mummert. 1982b. Filter-feeding rates of gizzard shad. Transactions of the American Fisheries Society 111:210-215.

Hambright, K. D., R. W. Drenner, S. J. McComas, and N. G. Hairston, Jr. 1991. Gape-limited piscivores, planktivore size refuges, and the trophic cascade hypothesis. Hydrobiologia 121:389-404.

Hartman, K. J., and S. B. Brandt. 1993. Systematic sources of bias in a bioenergetics model: examples for age-0 striped bass. Transactions of the American Fisheries Society 122:912-926.

Hewett, S. W., and B. L. Johnson. 1992. Fish bioenergetics model 2. University of Wisconsin, Sea Grant Institute, Technical Report WIS-SG-92-250, Madison.

Hjort, J. 1914. Fluctuations in great fisheries of northern Europe. Rapports et Procés-Verbaux des Réunions, Conseil International pour l'Exploration de la Mer 20:1-13.

Jahn, L. A., D. R. Douglas, M. J. Terhaar, and G. W. Kruse. 1987. Effects of stocking hybrid striped bass in Spring 
Lake, Illinois. North American Journal of Fisheries Management 7:522-530.

Johnson, B. M. 1986. Using a quadrat rotenone technique to evaluate forage fish size and abundance for stocked piscivores. Master's thesis. Ohio State University, Columbus.

Johnson, B. M., R. A. Stein, and R. F. Carline. 1988. Use of a quadrat rotenone technique and bioenergetics modeling to evaluate prey availability to stocked piscivores. Transactions of the American Fisheries Society 117:127-141.

Juanes, F. 1994. What determines prey size selectivity in piscivorous fishes? Pages 79-100 in D. J. Stouder, K. L. Fresh, and R. J. Fuller, editors. Theory and application in fish feeding biology. University of South Carolina Press, Columbia.

Kitchell, J. F. 1992. Food web management: a case study of Lake Mendota. Springer-Verlag, New York.

Layzer, J. B., and M. D. Clady. 1984. Evaluation of the striped bass $\times$ white bass hybrid for controlling stunted bluegills. Proceedings of the Annual Conference Southeastern Association of Fish and Wildlife Agencies 35(1981):297-310.

McQueen, D. J., M. R. Johannes, J. R. Post, T. J. Stewart, and D. R. S. Lean. 1989. Bottom-up and top-down impacts on freshwater pelagic community structure. Ecological Monographs 59:289-309.

Miller, R. R. 1960. Systematics and biology of the gizzard shad (Dorosoma cepedianum) and related fishes. Fishery Bulletin 60:371-392.

Miner, J. G. 1990. Turbidity-mediated predator-prey interactions among piscivores, prey fishes, and zooplankton. Doctoral dissertation. Ohio State University, Columbus.

Miner, J. G., and R. A. Stein. 1996. Detection of predators and habitat choice by small bluegills: effects of turbidity and alternative prey. Transactions of the American Fisheries Society 125:97-103.

Miranda, L. E. 1983. Average ichthyomass in Texas large impoundments. Annual Proceedings of the Texas Chapter, American Fisheries Society 6:58-67.

Morris, D. J., and B. J. Follis. 1979. Effects of striped bass upon shad in Lake E. V. Spence, Texas. Proceedings of the Annual Conference Southeastern Association of Fish and Wildlife Agencies 32(1978):697-702.

Ott, R. A., Jr., and S. P. Malvestuto. 1984. The striped bass $\times$ white bass hybrid in West Point Reservoir. Proceedings of the Annual Conference Southeastern Association of Fish and Wildlife Agencies 35(1981):641-646.

Pitcher, T. J. 1986. Functions of shoaling behavior in teleosts. Pages 294-337 in T. J. Pitcher, editor. The behavior of teleost fishes. Croom Helm, London.

Savino, J. F, and R. A. Stein. 1982. Predator-prey interactions between largemouth bass and bluegills as influenced by simulated, submersed vegetation. Transactions of the American Fisheries Society 111:255-266.

Stahl, T. P., and five coauthors. 1996. Factors affecting survival of age-0 saugeye Stizostedion vitreum $\times$ S. canadense stocked into Ohio reservoirs. North American Journal of Fisheries Management 16:378387.

Stein, R. A., M. T. Bremigan, and J. M. Dettmers. 1996. Understanding reservoir systems with experimental tests of ecological theory: a prescription for management. Pages 12-22 in L. E. Miranda and D. R. DeVries, editors. Multidimensional approaches to reservoir fisheries management. American Fisheries Society, Symposium 16, Bethesda, Maryland.

Stein, R. A., D. R. DeVries, and J. M. Dettmers. 1995. Food-web regulation by a planktivore: exploring the generality of the trophic cascade hypothesis. Canadian Journal of Fisheries and Aquatic Sciences 52:25182526.

Stewart, D. J., J. F. Kitchell, and L. B. Crowder. 1981. Forage fishes and their salmonid predators in Lake Michigan. Transactions of the American Fisheries Society 110:751-763.

Timmons, T. J., W. L. Shelton, and W. D. Davies. 1979. Sampling of reservoir fish populations with rotenone in littoral areas. Proceedings of the Annual Conference Southeastern Association of Fish and Wildlife Agencies 32(1978):474-484.

Timmons, T. J., W. L. Shelton, and W. D. Davies. 1981. Early growth and mortality of largemouth bass in West Point Reservoir, Alabama-Georgia. Transactions of the American Fisheries Society 110:489-494.

Vondracek, B., and R. LeHew. 1991. Population dynamics and ecology of Lake Erie gizzard shad. Ohio Department of Natural Resources, Federal Aid in Sport Fish Restoration, Project F-61-R, Final Report, Columbus.

Wahl, D. H., and R. A. Stein. 1993. Comparative population characteristics of muskellunge (Esox masquinongy), northern pike (E. lucius), and their hybrid (E. masquinongy $\times$ E. lucius). Canadian Journal of Fisheries and Aquatic Sciences 50:1961-1968.

Willis, D. W., and L. D. Jones. 1986. Fish standing crops in wooded and nonwooded coves of Kansas reservoirs. North American Journal of Fisheries Management 6:105-108. 
Woiwode, J. G., and I. R. Adelman. 1991. Effects of temperature, photoperiod, and ration size on growth of hybrid striped bass $\times$ white bass. Transactions of the American Fisheries Society 120:217-229.

Yako, L. A., J. M. Dettmers, and R. A. Stein. 1996. Feeding preferences of omnivorous gizzard shad as influenced by fish size and zooplankton density. Transactions of the American Fisheries Society 125: 741-747. 